\title{
Hydrocarbonoclastic potentials of Enterobacteriaceae isolated from the crude oil polluted Iko river estuary and freshwater ecosystem of the Niger Delta Region of Nigeria
}

\author{
Nkanang Abigail Johnny *, Antai Sylvester Peter, Asitok Atim David and Ekpenyong Maurice \\ Department of Microbiology, University of Calabar, Cross River State, Nigeria
}

Publication history: Received on 23 November 2017; revised on 19 December 2017; accepted on 08 January 2018

https://doi.org/10.30574/gscbps.2018.2.1.0058

\begin{abstract}
Hydrocarbonoclastic potentials of Enterobacteriaceae isolated from the crude oil polluted Iko river estuary and freshwater ecosystem of the Niger Delta was investigated. The isolation of crude oil utilizing bacterial isolates in water sample was carried out by surface spreading technique using diluents prepared with quarter strength Ringers solution and cultured on oil agar medium (OAM). Of the 32 potential hydrocarbon utilizing bacteria from crude oil impacted aquatic ecosystem only eight isolates identified as; Citrobacter amalonaticus-Y1 (FSW); Proteus mirabilis strain-I(FSW), Pseudomonas fluorescens-N (FSE); Citrobacter farmeri-Y12 (FSE), Citrobacter amalonaticus strain-Y2 (ESWS1), Enterobacter sp.-Y8 (ESWS3), Proteus mirabilis strain-K (ESWS1), Proteus penneri strain-O(ESES3) were found to demonstrate strong hydrocarbonoclastic potentials with variable levels of low $\mathrm{pH}$ and increase optical density and free carbon iv oxide production. The study revealed that Citrobacter amalonaticus strain-Y2 (ESWS1) of the family Enterobacteriaceae is a good candidate for bioaugmentation technique of bioremediation.
\end{abstract}

Keywords: Crude oil; Iko river; Hydrocarbonoclastic; Enterobacteriaceae; Bioaugmentation; Bioremediation

\section{Introduction}

The introduction of large quantity crude oil and other petroleum products occurring mainly during production and transportation processes usually exceeds the self - purification capability of the receiving water ecosystem. The effect of oil pollution on aquatic ecosystem is enormous. Contending oil spillage on water bodies possess a lot of challenges. It is harmful to birds and diverse aquatic lives. It incurs heavy economic and esthetic damage to the environment. Remediating costs of spillage are high often amounting to $\$ 10-15$ per gallon of spilled oil. Physical methods of driving off oil with detergents or dropping down oil with chalk or siliconized sand can only take away oil from the surface, but the exposure of aquatic lives to hydrocarbon pollutants is greatly increased. Predominant climatic and weather conditions can also hinder the cleanup of oil slicks [1].

Ruinous and unmanageable releases of hydrocarbon products result in environmental and ecological reverberation, in that most of the hydrocarbon compounds are toxic and relentless in the terrestrial and aquatic environments. Various physical and chemical methods are used in the removal of contaminants from the environment. However, bioremediation which is biologically mediated process to remove pollutants from contaminated environment is more effective. This involve the microbial mineralization of complex polymers into simple inorganic constituents such as carbon dioxide [2]. This method uses the metabolic capacities of microorganisms to remediate polluted environments. In bioremediation, the schemes used in cleaning up the contaminated ecosystems focus on either stimulating autochthonous microbial population by environmental alteration (biostimulation) or bringing in exogenous microbial species that are known to

${ }^{*}$ Corresponding author

E-mail address: abigailnkanang@ yahoo.com

Copyright (C) 2018 Author(s) retain the copyright of this article. This article is published under the terms of the Creative Commons Attribution Liscense 4.0. 
be pollutant degraders to a contaminated site (bioagumentation) [3-4]. Biological degradation is safe and it's application is simple and effective, at such it could be used as economic alternative on large areas. [5].

In aquatic and terrestrial environments, biodegradation of crude oil and other petroleum components predominantly revolves around the action of bacterial and fungal populations [3]. The outcome of an uninterrupted addition of petroleum-based pollutants is an enriched microbial community which has the ability to strive during toxic contamination. Microorganisms are responsive to changes in their environment. At such whenever there is a sudden change in the physical or chemical conditions in their environment, the organisms will experience a lag period during which the organisms is made fit for the new environmental conditions [6-7].This lag period is also called acclimatization period and enables microorganisms to acquire the metabolic repertoire necessary for their survival [8].

Hydrocarbonoclastic bacteria are hydrocarbon degrading bacteria. Hydrocarbonoclastic organisms exhibit inherent capability to utilize and assimilate polluting petroleum hydrocarbon as a sole source of carbon and energy with the evolution of carbon dioxide and water by oxidative process. This reaction leads to eventual disappearance of oil in the water bodies [9]. Hydrocarbon-degrading bacteria and fungi are widely distributed in aquatic and terrestrial habitats. Lee et al., [10] recommended the use of microbial seeding of oil slicks as a cleanup technique where physical removal is impracticable or as a concluding stage during cleanup of residual oil. The most common hydrocarbon degraders in aquatic ecosystems include members of the bacterial genera Pseudomonas, Mycobacterium, Bacillus, Flavobacterium, Alcaligenes, Streptomyces, Nocardia, Desulfovibrio, Acinetobacter, Corynebacterium, Thiobacillus, Klebsiella, Achromobacter, Serratia, Peptococcus, Peptostreptococcus, Azotobacter, Clostridium, Brevibacterium, Vibrio, Halobacterium, Bacteriodes and Proteus [11-12].

Hydrocarbon contamination of aquatic ecosystem is among the most evident negative impacts of the petroleum industry. Oil spills, oil transportation, drilling operation, refineries and local fuel filling stations are some of the causes responsible for hydrocarbon contamination [13]. Due to the oily nature and inability of hydrocarbons to dissolve in water, they are refractory. At such their persistence in the environment could cause perilous effect on plants and living organism of the terrestrial and aquatic ecosystems.

Hydrocarbonoclastic bacteria are important constituents of oil degrading consortia and are usually present in hydrocarbon contaminated sites. Due to their high degradation potentials, they have been utilized in remediating oil contaminated soil and aquatic ecosystems. Beside bacteria, some fungal species are known to have hydrocarbonoclastic potential. (Potential hydrocarbonoclastic Bacteria, https://www.biotecharticles.com/Applications-Article/PotentialHydrocarbonoclastic-Bacteria-730.html, last accessed on 03/10/2011).

One of the interesting features of hydrocarbonoclastic bacteria is their ability to proliferate rapidly in the presence of hydrocarbon. They proliferate effectively in the presence of aliphatic and aromatic hydrocarbons since they are heterotrophic in nature. Though most of the hydrocarbonoclastic bacteria can only grow in the presence of hydrocarbon, some members of these group sometimes utilize other substrate like acetate and pyruvate which are not hydrocarbon substrates. Sampling of hydrocarbonoclastic bacteria are often from hydrocarbon contaminated environments since they are not common in unpolluted environments (Potential hydrocarbonoclastic Bacteria, https://www.biotecharticles.com/Applications-Article/Potential-Hydrocarbonoclastic-Bacteria-730.html, last accessed on $03 / 10 / 2011$ ).

Oil contamination of aquatic ecosystem remains an on-going problem whether it originates from low-level discharge from refineries and drilling platforms or from more dramatic spills from tanker disasters. Spills result in considerable contamination of aquatic environment [14], but the impact of oil contamination is difficult to predict due to its complex nature. Although there are reports on hydrocarbon utilizing microorgannisms in various ecosystem [15-17], reports on the hydrocarbonoclastic potentials of bacteria is still at the toothing stage. Thus this study was undertaken to determine the hydrocarbonoclastic potentials of bacteria species of the family Enterobacterieceae isolated from Iko river estuary and freshwater ecosystem in the Niger Delta in order to determine their efficiency in bioaugmentation technique of bioremediaton. 


\section{Material and methods}

\subsection{Study area}

The study area lies within latitude $7^{\circ} 30^{\prime} \mathrm{N}$ and $7^{\circ} 45^{\prime} \mathrm{N}$ and longitude $7^{\circ} 30^{\prime} \mathrm{E}$ and $7^{\circ} 30^{\prime} \mathrm{E}$. The river takes its rise from Qua Iboe River catchment and drains into the Atlantic Ocean at the Bright of Bonny. The river is characterized by flood and ebb tides with shallow depth ranging from 1 to $7 \mathrm{~m} \mathrm{[17].}$

The Iko River estuary is formed by adjourning tributaries, creeks and channels. This provides an appropriate site for petroleum exploration and production activities, good fishing ground for artisan fishermen as well as breeding sites for diverse aquatic resources in the area. The Iko River shoreline is also characterized with tidal mud flats and mangrove vegetation - Neppa palm (Protium pneumaphores and exposed during low tides [17].

\subsection{Collection of water samples}

The surface water samples were aseptically collected into clean $1 \mathrm{~L}$ capacity plastic bottles. All containers were rinsed three times with water sample before collection [18]. All water samples were collected from the surface (10 to $25 \mathrm{~cm})$. The Nansen water bottle samplers were opened to fill and close below the water for subsurface water sample. Samples were then placed in an ice-cooled chest and transported immediately to the Microbiology Laboratory for analysis.

The analytical media employed in this research included nutrient agar (NA) and mineral salt medium (MSM) of Zajic and Supplison, [19]. Crude oil used was Bonny light crude oil collected from Qua Iboe Terminal, Ibeno, Akwa Ibom State and stored at room temperature.

\subsection{Isolation, enumeration and purification of crude oil utilizing bacterial isolates}

The vapour phase transfer technique method described in Asitok et al. [20] was used. Isolation of hydrocarbon utilizing bacteria in the water sample was carried out using the surface spread technique. Tenfold serial dilutions of the samples were made. Then $0.1 \mathrm{~mL}$ of the various dilutions were then plated in triplicates into mineral salt medium (MSM) supplemented with nystatin $\left(50 \mathrm{mg} \mathrm{L}^{-1}\right)$ to inhibit fungal growth. Thereafter, sterile filter paper (Whatman no. 1) saturated with $2.0 \mathrm{~mL}$ of filtered Bonny light crude oil were aseptically placed inside the covers of the inverted Petri dishes. The inoculated plates were then sealed around with a masking tape. This process enable the supply of hydrocarbons by vapour phase transfer as the carbon and energy source for colonies that developed on the agar surfaces. Inoculated plates were incubated at room temperature $\left(28 \pm 2{ }^{\circ} \mathrm{C}\right)$ for 5 to 7 days.

Developed colonies were enumerated and expressed as colony forming units per milliliter ( $\mathrm{cfu} \mathrm{ml}^{-1}$ ). Distinct colonies were purified by repeatedly transferring to freshly prepared nutrient agar plates by streak-plate method and subsequent storing on agar slants in the refrigerator $\left(4^{\circ} \mathrm{C}\right)$ for further use.

\subsection{Molecular characterization of hydrocarbon utilizing bacterial isolates}

DNA extraction was carried out with a 24 hours BHI broth microbial isolates harvested by centrifugation at $14,000 \mathrm{~g}$ for 10 minute. The cells were washed three times in $1 \mathrm{~mL}$ of ultra-pure water by centrifugation at $12,000 \mathrm{rpm}$ for $5 \mathrm{minutes}$.

DNA extraction and purification was done using ZR fungal/bacterial DNA Miniprep ${ }^{\text {TM }} 50$ Preps. Model D6005 (Zymo Research, California, USA). 50 - $100 \mathrm{mg}$ of bacterial cells were re-suspended in $200 \mu \mathrm{L}$ of sterile water. This was transferred to a ZR Bashing BeadTM Lysis Tube. Exactly $750 \mu \mathrm{L}$ analysis solution was added to the tube. The bead containing the solution was secure in a bead beater fitted with a $2 \mathrm{~mL}$ tube holder assembly and processed at maximum speed for 5 minutes. The ZR Bashing Bead ${ }^{\mathrm{TM}}$ Lysis Tube containing the bacterial cells was then centrifuged in a microcentrifuge at $10,000 \mathrm{~g}$ for $1 \mathrm{~min} .400 \mu \mathrm{L}$ of the supernatant was then pipetted into a zymo-spin ${ }^{\mathrm{TM}} \mathrm{IV}$ spin filter in a collection tube and centrifuged at 7,000 g for $1 \mathrm{~min}$. This was followed by the addition of 1,200 $\mu \mathrm{L}$ of fungal/bacterial DNA binding buffer into the filtrate in the collection tube. After this $800 \mu \mathrm{L}$ the mixture was transferred into a Zymo$\operatorname{spin}^{\mathrm{TM}} 11 \mathrm{C}$ column in a collection tube and centrifuge at $10,000 \mathrm{~g}$ for $1 \mathrm{~min}$. The flow through was discarded from the collection tube and the process was repeated to obtain the products. The $200 \mu \mathrm{L}$ DNA pre-wash buffer was added to the column in a new collection tube and then centrifuge at 10,000 g for $1 \mathrm{~min}$. $500 \mu \mathrm{L}$ fungal/bacterial DNA wash buffer was added into the Zymo-spin ${ }^{\mathrm{TM}}$ IIC column and centrifuged at 10,000 g for $1 \mathrm{~min}$. This was then transferred into a clean 1.5 $\mathrm{mL}$ micro centrifuge tube and $100 \mu \mathrm{L}$ of DNA elution buffer was then added to the column matrix. DNA was eluted by centrifuging at 10,000 g for 30 seconds. The resulting ultra-pure filtrate (DNA) obtained was then transported in ice pack to the biotechnology laboratory for sequencing. 
DNA sequencing was performed by Sanger (dieoxy) sequencing technique to determine the nucleotide sequence of the specific microorganism isolated using automated PCR cycle - Sanger sequencer ${ }^{\mathrm{TM}}$ 3730/3730 XL DNA Analyzer from Applied Biosystems. The results were obtained as nucleotide in FASTA format. Identification of the species were done using nucleotide base pairs. These were formed by BLAST analysis by direct blasting on http://blast.ncbi.nim.nih.gov. For every set of isolate, a read was BLASTED and the resultant top limit with minimum E-score for every BLAST result showing species name was used to name the specific organism.

\subsection{Determination of hydrocarbonoclastic potential of bacteria isolates}

The methods of Okpokwasili and Okorie [21] (modified) and procedure earlier reported by Esin and Antai [22] and Vanishree et al. [23] were employed. $9.9 \mathrm{~mL}$ of mineral salt broth (MSB) were dispensed were into test tubes and then autoclaved for sterilization. $0.1 \mathrm{~mL}$ of the filtered Bonny light crude oil was then added to the cooled MSB tubes. Thereafter, $0.1 \mathrm{~mL}$ of the 24 hour nutrient broth culture was then inoculated into different set of test tubes. Two control tubes were not inoculated and all the test tubes were incubated at room temperature $\left(28 \pm 2{ }^{\circ} \mathrm{C}\right)$ for 14 days.

At an interval of 4 days, the tubes were compared with the control and observed visually for turbidity as an index of utilization of the Bonny light crude oil. At the end of 14days, the ability to degrade oil were regarded as strong (+++), moderate $(++)$, and weak $(+)$ while inability to grow was recorded as no growth $(-)$. The final turbidity of the medium was read using HACH 2100P Turbidimetre, $\mathrm{pH}$ was measured by an electronic $\mathrm{pH}$ meter (HACH sension $3 \mathrm{pH}$ meter); optical density at $540 \mathrm{~mm}$ using HACH RD/210 spectrophotometer; Total viable count by serially diluting the culture, plating on nutrient agar and incubating at $\left(28 \pm 2{ }^{\circ} \mathrm{C}\right)$ for 24 hours and expressed as colony forming units per milliliter (CFU mL ${ }^{-1}$ ) and free $\mathrm{CO}_{2}$ determined by titrating $1 \mathrm{ml}$ of the fermented culture against $0.05 \mathrm{~N} \mathrm{NaCl}$ solution using phenolphthalein as an indicator and appearance of a stable pink colour as end point. The amount of $\mathrm{CO}_{2}$ was calculated using the formula:

$$
\text { Free } \mathrm{CO}_{2}\left(\frac{\mathrm{mg}}{\mathrm{L}}\right)=\frac{\text { Titre value } \times \text { Normality of } \mathrm{NaOH} \times 1000 \times 44}{\text { Volume of Sample }}
$$

\section{Results}

The sequencing result of hydrocarbonoclastic bacteria showing sequence homology and accession number of specie and strain in the gene bank is shown in table1.

The hydrocarbonoclastic potentials of bacteria isolated from the estuarine and freshwater ecosystems are presented in Table 2 . The screening test revealed that most of the microorganisms encountered in the Iko river estuary and freshwater were able to use the hydrocarbons as carbon and energy source. Table 2 shows Citrobacter amalonaticus - $\mathrm{Y}_{1}(\mathrm{FSW})$; Proteus mirabilis strain - I(FSW), Pseudomonas fluorescens - N(FSE); Citrobacter farmeri - Y12(FSE), Citrobacter amalonaticus strain - $\mathrm{Y}_{2}\left(\mathrm{ESWS}_{1}\right)$, Enterobacter $\mathrm{sp}-\mathrm{Y}_{8}\left(\mathrm{ESWS}_{3}\right)$, Proteus mirabilis strain - K(ESWS $)_{1}$, Proteus penneri strain - $\mathrm{O}\left(\mathrm{ESES}_{3}\right)$ which exhibited abundant growth on the crude oil minimal medium, lower $\mathrm{pH}$ and caused the evolution of a higher amount of free $\mathrm{CO}_{2}$ indicating a strong hydrocarbonoclastic potential. Others encountered in the ecosystem demonstrated weak or fairly strong oil degrading capabilities. 
Table 1 Sequencing result showing the sample numbers and the corresponding accession numbers and identity of organism

\begin{tabular}{|c|c|c|c|c|c|c|c|}
\hline $\begin{array}{l}\text { Sr. } \\
\text { No. }\end{array}$ & $\begin{array}{l}\text { Original } \\
\text { Number }\end{array}$ & $\begin{array}{l}\text { Sample } \\
\text { Type }\end{array}$ & $\begin{array}{l}\text { DNA } \\
\text { Type }\end{array}$ & $\begin{array}{c}\text { Gene } \\
\text { Bank } \\
\text { Accession } \\
\text { Number } \\
\end{array}$ & $\begin{array}{l}\text { Percentage } \\
\text { Match } \\
(\%)\end{array}$ & $\begin{array}{c}\text { Organism in the Gene } \\
\text { Bank }\end{array}$ & ID of Organism \\
\hline 1 & I & DNA & Genomic & KR133627 & 92 & $\begin{array}{l}\text { Proteus mirabilis strain } \\
\text { RBX1 }\end{array}$ & $\begin{array}{l}\text { Proteus mirabilis } \\
\text { strain-I(FSW) }\end{array}$ \\
\hline 2 & M & DNA & Genomic & JX393013 & 85 & $\begin{array}{l}\text { Morganella morganii } \\
\text { strain ZW45-1 }\end{array}$ & Morganella morganii \\
\hline 3 & $\mathrm{~N}$ & DNA & Genomic & KM206793 & 87 & $\begin{array}{l}\text { Pseudomonas } \\
\text { fluorescens } \mathrm{WN}-1\end{array}$ & $\begin{array}{l}\text { Pseudomonas } \\
\text { fluorescens - N(FSE) }\end{array}$ \\
\hline 4 & 0 & DNA & Genomic & KC456589 & 95 & $\begin{array}{l}\text { Proteus penneri strain } \\
\text { ALK624 }\end{array}$ & $\begin{array}{l}\text { Proteus penneri } \\
\text { strain- O(ESES3) }\end{array}$ \\
\hline 5 & $\mathrm{~S}$ & DNA & Genomic & СР009450 & 84 & $\begin{array}{l}\text { Pluralibacter gergoviae } \\
\text { strain FB2 }\end{array}$ & $\begin{array}{l}\text { Pluralibacter } \\
\text { gergoviae - }\end{array}$ \\
\hline 6 & $\mathrm{~T}$ & DNA & Genomic & СР001407 & 86 & $\begin{array}{l}\text { Bacillus } \\
\text { 03BB102 }\end{array}$ & $\begin{array}{l}\text { Bacillus cereus- } \\
\text { T(ESSWS3) }\end{array}$ \\
\hline 7 & B2 & DNA & Genomic & AY279207 & 80 & $\begin{array}{l}\text { Bacillus substilis strain } \\
\text { HA401 }\end{array}$ & $\begin{array}{l}\text { Bacillus substilis } \\
\text { strain-B2(ESWS1) }\end{array}$ \\
\hline 8 & $\mathrm{C} 3$ & DNA & Genomic & KR133627 & 88 & $\begin{array}{l}\text { Proteus mirabilis strain } \\
\text { RBX1 }\end{array}$ & $\begin{array}{l}\text { Proteus mirabilis } \\
\text { strain- C3(ESWS2) }\end{array}$ \\
\hline 9 & $\mathrm{D} 4$ & DNA & Genomic & HE575920 & 100 & Citrobacter farmeri & $\begin{array}{l}\text { Citrobacter farmeri- } \\
\text { D4(FSE) }\end{array}$ \\
\hline 10 & E5 & DNA & Genomic & KP260658 & 96 & $\begin{array}{l}\text { Enterobacter } \\
\text { hormeachei strain DD3 }\end{array}$ & $\begin{array}{l}\text { Enterobacter } \\
\text { hormeachei } \\
\text { E5(ESWS2) }\end{array}$ \\
\hline 11 & Y1 & DNA & Genomic & DQ187379 & 93 & $\begin{array}{l}\text { Citrobacter } \\
\text { amalonaticus }\end{array}$ & $\begin{array}{l}\text { Citrobacter } \\
\text { amalonaticus-1(FSW) }\end{array}$ \\
\hline 12 & Y2 & DNA & Genomic & FN667808 & 96 & $\begin{array}{l}\text { Citrobacter } \\
\text { amalonaticus strain } \\
\text { ADR61 }\end{array}$ & $\begin{array}{l}\text { Citrobacter } \\
\text { amalonaticus strain- } \\
\text { Y2(ESWS1) }\end{array}$ \\
\hline 13 & Y3 & DNA & Genomic & & & No amplification & \\
\hline 14 & Y7 & DNA & Genomic & DQ187383 & 94 & Citrobacter farmeri & $\begin{array}{l}\text { Citrobacter farmeri - } \\
\text { Y7 (FSE) }\end{array}$ \\
\hline 15 & Y8 & DNA & Genomic & HQ268733 & 97 & Enterobacter sp P2B & $\begin{array}{l}\text { Enterobacter sp - } \\
\text { Y8(ESWS3) }\end{array}$ \\
\hline 16 & Y9 & DNA & Genomic & KC456538 & 97 & $\begin{array}{l}\text { Proteus mirabilis strain } \\
\text { ALK0 } 43\end{array}$ & $\begin{array}{l}\text { Proteus mirabilis strain } \\
\text { - Y9(ESSWS1) }\end{array}$ \\
\hline 17 & Y12 & DNA & Genomic & DQ187383 & 96 & Citrobacter farmeri & $\begin{array}{l}\text { Citrobacter farmeri - } \\
\text { Y12(FSE) }\end{array}$ \\
\hline 18 & $\mathrm{~K}$ & DNA & Genomic & KJ206073 & 99 & $\begin{array}{l}\text { Proteus mirabilis strain } \\
13 \mathrm{a}\end{array}$ & $\begin{array}{l}\text { Proteus mirabilis } \\
\text { strain- K(ESWS1) }\end{array}$ \\
\hline 19 & Act3 & DNA & Genomic & KP117097 & 99 & $\begin{array}{l}\text { Proteus mirabilis strain } \\
\text { CIFRI H-TSB-70 }\end{array}$ & $\begin{array}{ll}\text { Proteus } & \text { mirabilis } \\
\text { strain-Act3 }\end{array}$ \\
\hline 20 & Act2 & DNA & Genomic & JF775415 & 97 & $\begin{array}{l}\text { Proteus mirabilis strain } \\
\text { YCG36 }\end{array}$ & $\begin{array}{l}\text { Proteus mirabilis } \\
\text { strain-Act2 }\end{array}$ \\
\hline
\end{tabular}


Table 2 Hydrocarbonoclastic potential of bacterial isolates from Iko estuarine and fresh water ecosystem

\begin{tabular}{|c|c|c|c|c|c|c|}
\hline $\mathbf{S} / \mathbf{N}$ & $\begin{array}{l}\text { Isolate } \\
\text { Code }\end{array}$ & Isolates & $\begin{array}{l}\text { Optical } \\
\text { Density } \\
(540 \mathrm{~nm})\end{array}$ & $\begin{array}{c}\text { Turbidity } \\
\text { (Visual) }\end{array}$ & pH & $\begin{array}{c}\text { Free } \mathrm{CO}_{2} \\
\mathrm{mg} / \mathrm{L}\end{array}$ \\
\hline 1 & A & Control & 0.082 & - & 7.23 & 11 \\
\hline 2 & $\mathrm{~F}$ & Vibrio sp & 0.0964 & + & 7.26 & 294.25 \\
\hline 3 & $\mathrm{E}_{5}$ & Enterobacter hormeachei strain - $\mathrm{E}_{5}\left(\mathrm{ESWS}_{2}\right)$ & 0.186 & ++ & 6.5 & 349.25 \\
\hline 4 & $\mathrm{Y}$ & Corynebacterium sp & 0.194 & + & 7.13 & 255.75 \\
\hline 5 & $\mathrm{C}_{3}$ & Proteus mirabilis strain $-\mathrm{C}_{3}\left(\mathrm{ESWS}_{2}\right)$ & 0.18 & ++ & 6.26 & 437.25 \\
\hline 6 & $\mathrm{~B}_{2}$ & Bacillus substilis strain- $\mathrm{B}_{2}\left(\mathrm{ESWS}_{1}\right)$ & 0.247 & ++ & 6.21 & 442.75 \\
\hline 7 & Act $_{2}$ & Proteus mirabilis strain- Act $_{2}$ & 0.179 & ++ & 6.18 & 363 \\
\hline 8 & $\mathrm{H}$ & Chromatum sp & 0.394 & + & 7.3 & 250.25 \\
\hline 9 & $\mathrm{Y}_{2}$ & Citrobacter amalonaticus strain $-\mathrm{Y}_{2}(\mathrm{FSW})$ & 1.79 & +++ & 6.15 & 517 \\
\hline 10 & $\mathrm{~J}$ & Actinomyces sp & 0.198 & + & 7.18 & 277.75 \\
\hline 11 & $\mathrm{Y}_{1}$ & Citrobacter amalonaticus $-\mathrm{Y}_{1}\left(\mathrm{ESWS}_{1}\right)$ & 1.987 & +++ & 6.02 & 563 \\
\hline 12 & $\mathrm{~K}$ & Proteus mirabilis strain- K(ESWS 1$)$ & 1.412 & +++ & 6.19 & 459.25 \\
\hline 13 & $\mathrm{~L}$ & Micrococcus sp & 0.307 & ++ & 6.14 & 352 \\
\hline 14 & $\mathrm{Y}_{8}$ & Enterobacter $\mathrm{sp}-\mathrm{Y}_{8}\left(\mathrm{ESWS}_{3}\right)$ & 1.42 & +++ & 6.2 & 467.5 \\
\hline 15 & I & Proteus mirabilis strain I(FSW) & 1.469 & +++ & 6.15 & 473 \\
\hline 16 & M & Morganella morganii & 0.293 & + & 7.21 & 269.5 \\
\hline 17 & $\mathrm{P}$ & Chromatium sp & 0.281 & + & 7.25 & 247.5 \\
\hline 18 & Q & Staphylococcus aureus & 0.243 & + & 7.27 & 228.75 \\
\hline 19 & $\mathrm{R}$ & Serratia sp & 0.316 & + & 7.14 & 291.5 \\
\hline 20 & $\mathrm{~S}$ & Plualibacter gergoviae & 0.148 & + & 7.55 & 198 \\
\hline 21 & $\mathrm{~T}$ & Bacillus cereus - T(ESSWS $\left.{ }_{3}\right)$ & 0.318 & ++ & 6.82 & 302.5 \\
\hline 22 & $Y_{9}$ & Proteus mirabilis strain - $\mathrm{Y}_{9}\left(\mathrm{ESSWS}_{1}\right)$ & 0.325 & ++ & 6.66 & 379.5 \\
\hline 23 & $\mathrm{~V}$ & Klebsiella sp & 0.312 & ++ & 7.63 & 361.25 \\
\hline 24 & 0 & Proteus penneri strain - O(ESES 3 & 1.413 & +++ & 6.23 & 440 \\
\hline 25 & W & Staphylococcus aureus & 0.247 & + & 7.35 & 211.75 \\
\hline 26 & $\mathrm{X}$ & Norcardia sp & 0.251 & + & 7.16 & 280.5 \\
\hline 27 & $\mathrm{D}_{4}$ & Citrobacter farmeri- $\mathrm{D}_{4}(\mathrm{FSE})$ & 0.324 & ++ & 6.12 & 393.25 \\
\hline 28 & $\mathrm{Y}_{12}$ & Citrobacter farmeri - Y12(FSE) & 1.375 & +++ & 6.1 & 404.25 \\
\hline 29 & $\mathrm{Z}$ & Serretia sp & 0.343 & + & 7.51 & 272.25 \\
\hline 30 & $\mathrm{~N}$ & Pseudomonas fluorescens - N(FSE) & 1.414 & +++ & 6.13 & 451 \\
\hline 31 & $\mathrm{Y}_{7}$ & Citrobacter farmeri - $\mathrm{Y}_{7}$ (FSE) & 0.327 & ++ & 6.5 & 376.75 \\
\hline 32 & Act $_{3}$ & Proteus mirabilis strain - Act $_{3}$ & 0.315 & ++ & 6.47 & 361.25 \\
\hline
\end{tabular}




\section{Discussion}

Many microorganisms are able to use various petroleum products as their major carbon and energy source though these hydrocarbon are insoluble in aqueous phase. Itah and Essien [24] reported that the hydrocarbonoclastic activities of microorganisms is greatly determined by the ability of the organisms to elaborates the vital enzymes required for the decomposition of the recalcitrant components of hydrocarbons. Most of these organisms belong to genera Pseudomonas, Bacillus, Aeromonas, Alcaligenes, Acinetobacter, Mycobacterium, Rhodococcus and Sphingomonas sp [25]. In this study, hydrocarbonoclastic potential of estuarine and freshwater microorganisms was accessed using indirect (the optical density, $\mathrm{pH}$, viable count and free carbon dioxide evolution) procedures. Citrobacter amalonaticus strain - $\mathrm{Y}_{2}\left(\mathrm{ESWS}_{1}\right)$, Proteus mirabilis strain - I(FSWS), Pseudomonas fluorescens- N(FSE), Citrobacter farmer- Y12(FSE), Citrobacter amalonaticus -- $\mathrm{Y}_{1}(\mathrm{FSW})$ Enterobacter sp- $\mathrm{Y}_{8}\left(\mathrm{ESWS}_{3}\right)$, Proteus mirabilis strain- K(ESWS $)_{1}$, Proteus penneri strain$\mathrm{O}\left(\mathrm{ESES}_{3}\right)$ were found to be the bacteria with high hydrocarbonoclastic potential.

Citrobacter amalonaticus strain - $\mathrm{Y}_{2}\left(\mathrm{ESWS}_{1}\right)$, exhibited a very strong hydrocarbonoclastic potential, the role of Citrobacter amalonaticus in utilization of crude oil and its products has previously been reported by Irshaid and Jacob [26]. Obst et al., [27] reported that Citrobacter amalonaticus utilized dipeptides released from cyanophycin granule polypeptide by another bacterium. Pseudomonas fluorescens - N (FSE), also demonstrated the ability of utilizing crude oil. This corroborates with the report of Gomathy and Senthilkumar [25] who reported that Pseudomonas fluorescens ability to utilize crude oil could be due to the haemolytic and emulsification of crude oil by the species. Proteus mirabilis- I (FSWS), and Proteus penneri strain -O (ESES 3 ) were observed in this study to utilize crude oil. Similar findings have revealed that Proteus species are more tolerant to high levels of hydrocarbons [28].

\section{Conclusion}

The study has shown that of the eight bacterial isolates of the family Enterobacterioceae that had strong hydrocarbonoclastic potential in hydrocarbon degradation, Citrobacter amalonaticus strain - $\mathrm{Y}_{2}\left(\mathrm{ESWS}_{1}\right)$ was outstanding. Citrobacter amalonaticus is added to the long list of hydrocarbon degrading bacteria species in the Niger Delta area of Nigeria and therefore set it apart as a good candidate for bioaugmentation technique of bioremediation.

\section{Compliance with ethical standards}

\section{Acknowledgments}

Gratitude for the tremendous contributions of the various authors. We also acknowledge the relevant contributions from Nigerian Institute of Medical Research, Yaba, in the molecular studies as well as others who made one or so positive contributions to the work.

\section{Disclosure of conflict of interest}

Authors have declared that no competing interest exist.

\section{References}

[1] Muncaster SP, Jacobson G, Taiarui M, King S and Bird S. (2016). Effects of MV Rena heavy fuel oil and dispersed oil on yellowtail kingfish early life stages. New Zealand Journal of Marine and Freshwater Research, 50(1), 131-143.

[2] Adams GA, Fufeyin PT, Okoro SE and Ehinomen I. (2015). Bioremediation, biostimulation and bioaugmention: A review. International Journal of Environmental Bioremediation and Biodegradation, 3(1), 28-39.

[3] Olukunle OF. (2013). Characterization of indigenous microorganisms associated with crude oil-polluted soils and water using traditional techniques. Microbiology Journal, 3, 1-11.

[4] Chikere CB, Okpokwasili GC and Chikere BO. (2011). Monitoring of microbial hydrocarbon remediation in the soil. Biotechnology, 3(1), 117-138.

[5] Javaid MK, Ashiq M and Tahir M. (2016). Potential of biological agents in decontamination of agricultural soil. Scientifica, 1-9.

[6] Chu D and Barnes DJ. (2016). The Lag-phase during diauxic growth is a trade-off between fast adaptation and high growth rate. Scientific reports, 6, 25191. 
[7] Oyedeji AA. (2016). Impacts of selected leguminous tree species and kaolinite pre-amendment on oilcontaminated soil for bioremediation in the oil-bearing region of Nigeria. Ph. D. thesis, University of Wolverhampton, UK.

[8] Etuk CU, John RC, Ekong UE and Akpan MM. (2012). Growth study and hydrocarbonoclastic potential of microorganisms isolated from aviation fuel spills site in Ibeno. Nigeria Bulletin of Environmental Contamination and Toxicology, 89, 727-732.

[9] Chikere CB, Okpokwasili GC and Ichiakor 0. (2009). Characterization of hydrocarbon utilizing bacteria in tropical marine sediments. African Journal of Biotechnology, 8 (11), 2541-2544.

[10] Lee K, Boudreau M, Bugden J, Burridge L, Cobanli SE, Courtenay S, Grenon S, Hollebone B, Kepkay P and Li Z. (2011). State of knowledge review of fate and effect of oil in the arctic marine environment. A report prepared for the National Energy Board of Canada.

[11] John RC, Itah AY, Essien JP and Ikpe DI. (2011). Fate of nitrogen-fixing bacteria in crude oil contaminated wetland ultisol. Bulletin Environmental Contamination and Toxicology, 87, 343-353

[12] Reghuvaran A, Jacob K and Ravindranath, A. (2012). Isolation and characterization of nitrogen fixing bacteria from raw Coir Pith. African Journal of Biotechnology, 11(27), 7063-7071.

[13] Akan OD, Etok CA and Adegoke AA. (2013). Bioremediation of crude oil contaminated soil using wood ash. Journal of Pure and Applied Microbiology, 7(3), 1749-1756.

[14] Croquer A, Bone D, Bastidas C, Ramos R and García E. (2016). Monitoring coastal pollution associated with the largest oil refinery complex of Venezuela. PeerJ 4, e2171.

[15] Abdulsalam S, Adefila SS, Bugaje IM and Ibrahim S. (2013). Bioremediation of soil contaminated with used motor oil in a closed system. Bioremediation and Biodegradation, 3, 100-172.

[16] Jain PK, Gupta VK, Gaur RK, Lowry M, Jaroli DP and Chaukan UK. (2011). Bioremediation of petroleum oil contaminated soil and water. Research Journal of Environment Toxicology, 5(1), 1 - 26.

[17] Udotong IR, Eduok SI, Essien JP and Ita BN. (2008). Density of hydrocarbonoclastic bacteria and polycyclic aromatic hydrocarbon accumulation in Iko river mangrove ecosystem, Nigeria. International Journal of Environmental, Chemical, Ecological, Geological and Geophysical Engineering, 2(8), 121-127.

[18] American Public Health Association (APHA). (2005). Standard methods for the examination of water and wastewater. $21^{\text {st }}$ ed. American Public Health Association, Washington DC, 1220.

[19] Zajic JE and Supplisson B. (1972). Emulsification and degradation of "Bunker C" fuel oil by microorganisms. Biotechnology and Bioengineering, 14(3), 331-343.

[20] Asitok,A. D.,Antai, S.P. and Ekpeyong, M. G. (2017).Water soluble fraction of crude oïl uncouples protease biosynthesis and activity in hydrocarbonoclastic bacteria ; implications for natural attenuation. International Journal of Sciences, 6(7), 5-21.

[21] Esin AA and Antai SP. (2002). Biodegradability of the major components of Bonny light crude oil by Bacillus subtilis. Global Journal of pure and Applied Science, 8 (2), 215-222.

[22] Vanishree M, Thatheyus AJ and Ramya D. (2014). Biodegradation of petrol using Aspergillus sp. Annual Research and Review in Biology, 4(6), 914 - 923.

[23] Itah AY and Essien JP. (2005). Growth profile and hydrocarbonoclastic potential of microorganisms isolated from tarballs in the Bight of Bonny, Nigeria. World Journal of Microbiology and Biotechnology, 21(6), 1317-1322.

[24] Gomathy and Senthilkumar R. (2012). Distribution of hydrocarbanoclastic bacteria in Cuddalore coastal water and their emulsification potential on crude oil. International Journal of Research in Biological Sciences, 2(3), 107-112.

[25] Irshaid FI and Jacob JH. (2015). Screening and characterization of aerobic xylene-degrading bacteria from gasoline contaminated soil sites around gas stations in Northern Jordan. Journal of Biological Sciences, 15(4), 167-176.

[26] Obst MA, Krug H, Luftmann A and Steinbuchel K. (2005). Degradation of cyanophycin by Sedimentibacter hongkongensis strain $\mathrm{KI}$ and Citrobacter amalonaticus strain G isolated from an anaerobic bacterial consortium. Applied Environmental Microbiology, 71, 3642-3652. 
[27] Abdulsalam S, Bugaje IM, Adefila SS and Ibrahim S. (2011). Comparison of biostimulation and bioaugmentation for remediation of soil contaminated with spent motor oil. International Journal of Environmental Science and Technology, 8(1), 187-194.

\section{How to cite this article}

Nkanang AJ, Antai SP, Asitok AD and Ekpenyong M. (2018). Hydrocarbonoclastic potentials of Enterobacteriaceae isolated from the crude oil polluted Iko river estuary and freshwater ecosystem of the Niger Delta Region of Nigeria. GSC Biological and Pharmaceutical Sciences, 2(1), 38-46. 